九州大学学術情報リポジトリ

Kyushu University Institutional Repository

\title{
Application of Fly Ash to Acidic Soil to Improve Plant Growth in Disturbed Land of Open- cut Mining
}

Hamanaka, Akihiro

Department of Earth Resources Engineering, Faculty of Engineering, Kyushu University : Assistant Professor

YAMASAKI, Hiroto

Department of Earth Resources Engineering, Graduate School of Engineering, Kyushu University

Sasaoka, Takashi

Department of Earth Resources Engineering, Faculty of Engineering, Kyushu University : Associate Professor

Shimada, Hideki

Department of Earth Resources Engineering, Faculty of Engineering, Kyushu University : Professor

他

http://hdl. handle. net/2324/4355473

出版情報: Proceedings of the 18th Symposium on Environmental Issues and Waste Management in Energy and Mineral Production : SWEMP 2018, pp. 129-137, 2018-12-07. Springer Nature バージョン :

権利関係 : 


\title{
Application of Fly Ash to Acidic Soil to Improve Plant Growth in Disturbed Land of Open-cut Mining
}

\author{
A. Hamanaka ${ }^{1}$, H. Yamasaki ${ }^{1}$, T. Sasaoka ${ }^{1}$, H. Shimada ${ }^{1}$, and S. Matsumoto ${ }^{2}$ \\ ${ }^{1}$ Department of Earth Resources Engineering, Kyushu University, Japan \\ ${ }^{2}$ Geological Survey of Japan, National Institute of Advanced Industrial Science and \\ Technology (AIST), Japan \\ Email of Corresponding author: hamanaka@mine.kyushu-u.ac.jp
}

\begin{abstract}
The amount of fly ash disposed as industrial wastes is increasing with increasing coal demands all over the world. Although fly ash is generally disposed by landfill, the demand of effective utilization of them is increasing because of the limitation of the disposal site. $80 \%$ of coal ash is utilized such as a material for cements though less of them are disposed by landfill. Considering the preparation of landfill area and environmental issues, it is very meaningful to discuss the utilization of fly ash except a cement usage. Most of coal is mined by open-pit mining method in Indonesia. A broad post-mining area is built after the mining operation. The broad area has to be revegetated in terms of environmental conservation. However, soil acidification caused by mixing acid sulfate rocks or soils mined in the operation influences the revegetation. As the plant growth is inhibited under the acidic conditions, the utilization of fly ash which has higher neutralizing capacity due to its alkalinity is expected in order to improve the conditions of seedbed in the revegetation area. In this paper, the utilization of fly ash for preparation of seedbed in disturbed land in Indonesian open cut coal mine is discussed by means of laboratory vegetation test by using simulated acidic soil with a mixture of pyrite, fly ash which has higher alkalinity, and Acacia mangium which is a typical species planted for fast growing tree in Indonesia. The results suggested that the appropriate mixture of fly ash to neutralize the acidic soil can be improved the plant growth under the acidic condition.
\end{abstract}

Keywords: Acid Soils, Fly Ash, Plant Growth, Rehabilitation

\section{Introduction}

Rehabilitation of post-mine land is necessary for sustainable development of opencut mining. Minerals are mined with the destruction of surface structure, such as forest and grasses, in open-cut mining. Thus, rehabilitation of post-mine land is required at the end of the development for environmental conservation. In open-cut mining, topsoil, which is formed from the surface down to approximately $1.0 \mathrm{~m}$ depth, is stored during the excavation stage, followed by the placement in surface layer in post-mine land during rehabilitation since they contain much nutrition that is useful 
for plant growth [1]. However, the shortage of topsoil attributing to the loss while hauling soil results in the difficulty of rehabilitation in some cases. Furthermore, the loss of topsoil caused by soil erosion or landslide causes the inhibition of plant growth in the post mined land, leading to the failure of rehabilitation [1], [2]. Therefore, it is important to secure enough amount of topsoil for rehabilitation in the disturbed land of open-cut mining.

In many mines, acid sulfate soils and/or rocks are mined as waste materials with excavation of minerals [3]. These soils and/or rocks consist of several kinds of minerals such as silicate and sulfide minerals (e.g. pyrite: $\mathrm{FeS}_{2}$ ). This sulfide mineral leads to Acid Mine Drainage (AMD) when they are exposed to oxygen and water during excavation process as follows:

$$
\begin{gathered}
\mathrm{FeS}_{2}+7 / 2 \mathrm{O}_{2}+\mathrm{H}_{2} \mathrm{O} \rightarrow \mathrm{Fe}^{2+}+2 \mathrm{SO}_{4}{ }^{2-}+2 \mathrm{H}^{+} \\
\mathrm{Fe}^{2+}+1 / 4 \mathrm{O}_{2}+\mathrm{H}+\rightarrow \mathrm{Fe}^{3+}+1 / 2 \mathrm{H}_{2} \mathrm{O} \\
\mathrm{Fe}^{3+}+3 \mathrm{H}_{2} \mathrm{O} \rightarrow \mathrm{Fe}(\mathrm{OH})_{3}+3 \mathrm{H}^{+} \\
\mathrm{FeS}_{2}+14 \mathrm{Fe}^{3+}+8 \mathrm{H}_{2} \mathrm{O} \rightarrow 15 \mathrm{Fe}^{2+}+2 \mathrm{SO}_{4}{ }^{2-}+16 \mathrm{H}^{+}
\end{gathered}
$$

The waste materials are classified as Potentially Acid Forming (PAF) by means of several geochemical tests: PAF is the source of AMD. PAF is, generally, backfilled under the ground to prevent the occurrence of AMD. However, they are mixed in topsoil and backfilled in surface layer in the post-mining land in some cases [4]. In this situation, the mixing of such waste materials consisted of PAF in topsoil causes soil acidification, and this affects revegetation process in mining operation. In fact, the failure of revegetation by soil acidification attributed to metal dissolutions with PAF was reported in Indonesian open cut-coal mines [5]. However, another researcher reported vegetation growth can be promoted if the soil quality is good for plant growth although the soil contains high metal contents [6].

As for the vast amount of fly ash produced as the industrial wastes in a coal-fired power plant, the effective utilization ways are expected in some applications as alternatives for natural materials. Much of fly ash is utilized such as a material for cements though less of them are disposed by landfill. Considering the preparation of landfill area and environmental issues, it is very meaningful to discuss the utilization of fly ash except a cement usage. Besides, the potential to utilize fly ash for biomass production has indicated [7]. Several studies have shown that the fly ash application on topsoil can promote the plant growth because it can increase $\mathrm{pH}$ of the acid soil [8], [9], [10], improve the soil structure [11], and supply the trace element which is necessary for plant growth [12]. On the other hands, careful consideration is needed when the amendment of topsoil using fly ash is discussed because the excess addition of fly ash causes the decrease of plant growth due to the salinity of the soils and impact from toxic elements [13], [14]. Given these facts, several researchers suggested the allowable range of fly ash addition to the soil based on pot experiment 
[14], [15]. However, the use of fly ash for soil amendment is a complicated topic because the properties of fly ash and acidic soils are site specific.

The present work is focused on addition of fly ash which has high alkaline to two acidic soils which has different potential of metal leachate. Therefore, the utilization of fly ash for preparation of seedbed in disturbed land in open-cut mine is discussed by means of laboratory vegetation test using simulated acidic soil with a mixture of pyrite, fly ash which has higher alkalinity, and Acacia mangium which is a typical species planted for fast growing tree in the beginning stage of revegetation.

\section{Material and Methods}

\subsection{Preparation of simulated soil for vegetation test}

Simulated acid soil was prepared by mixing decomposed granite soil and pyrite. In this study, two types of acidic soils were prepared to simulate the different potential of metal leachate from the soil. Besides, fly ash (FA) was taken in the coal fired power plant in Japan. Table 1 shows fundamental properties of each sample. Paste $\mathrm{pH}$ and EC tests were carried out by the dissolution process with sample and deionized water. The mixing ratio of sample and deionized water was the 1:2.5 in the paste $\mathrm{pH}$ and 1:5 in the paste EC, respectively. From the Table 1, the acidic soil 2 shows the lower $\mathrm{pH}$ and higher EC compared to acidic soil 1, meaning that the potential of metal leachate is higher. Fly ash has the higher alkalinity and the dominant particle size is silt.

Table 1. Soil compositions, Paste $\mathrm{pH}$, Paste EC of each sample.

\begin{tabular}{ccccccc}
\hline Sample & Sand (\%) & Silt (\%) & Clay (\%) & Soil Texture & Paste pH & $\begin{array}{c}\text { Paste EC } \\
(\mathrm{mS} / \mathrm{cm})\end{array}$ \\
\hline Acidic soil 1 & 84.5 & 7.3 & 8.3 & Sandy Loam & 3.70 & 1.32 \\
Acidic soil 2 & 85.8 & 7.2 & 7.0 & Sandy Loam & 3.10 & 3.50 \\
Fly ash & 9.0 & 75.3 & 15.7 & Silt Loam & 12.60 & 3.20 \\
\hline
\end{tabular}

Next, paste $\mathrm{pH}$ and $\mathrm{EC}$ tests, dissolution metal ion analysis, and permeability test based on ASTM D5084-10 standard were conducted for 10 types of samples which were prepared by changing the mixture rate of simulated acidic soil and fly ash (Tables 2 and 3). Paste $\mathrm{pH}$ rises with an increase of mixing ratio of fly ash in both acidic soils 1 and 2. Above all, excess addition of fly ash causes soil alkalization in acidic soil 1 because the paste $\mathrm{pH}$ shows alkaline when the mixture ratio of fly ash is more than $20 \%$. Paste EC declines under the neutral $\mathrm{pH}$ condition when the fly ash mixture ratio is $5 \%$ and $10 \%$ for acidic soil 1 and more than $10 \%$ for acidic soil 2 , respectively. This fact indicates that metal dissolution can be minimized by controlling the soil $\mathrm{pH}$. However, the remediation of paste $\mathrm{EC}$ in acidic soil 2 is not enough due to the high potential of metal dissolution from acidic soil based on the 
standard [16]. The hydraulic conductivity is slightly decreased with an addition of fly ash. Table 3 shows the result of metal ion analysis by using the water from paste EC test. The major metal contents eluted in $\mathrm{AMD}$, such as $\mathrm{Al}, \mathrm{Fe}$, and $\mathrm{Mn}$, were measured in this test. The dissolution of $\mathrm{Al}$ causes the inhibition of plants growth due to the elongation of roots of plants [17], [18]. Additionally, Fe derived from the pyrite is a dominant metal ion eluted under the acidic conditions, and its concentration is higher in acidic soil 2.

Table 2. Paste $\mathrm{pH}$, Paste EC, hydraulic conductivity of simulated soils.

\begin{tabular}{ccccc}
\hline & Fly ash (\%) & Paste $\mathrm{pH}$ & Paste EC (mS/cm) & Hydraulic conductivity $(\mathrm{cm} / \mathrm{s})$ \\
\hline & 0 & 3.70 & 1.32 & $5.70 \times 10^{-4}$ \\
Acidic Soil 1 & 5 & 5.90 & 1.06 & $2.16 \times 10^{-4}$ \\
& 10 & 6.35 & 1.20 & $1.34 \times 10^{-4}$ \\
& 20 & 8.44 & 1.33 & $1.13 \times 10^{-4}$ \\
& 50 & 11.22 & 1.49 & $1.56 \times 10^{-5}$ \\
\hline \multirow{3}{*}{ Acidic Soil 2 } & 0 & 3.10 & 3.50 & $7.43 \times 10^{-4}$ \\
& 5 & 4.83 & 3.30 & $2.84 \times 10^{-4}$ \\
& 10 & 5.64 & 2.80 & $1.45 \times 10^{-4}$ \\
& 20 & 6.13 & 2.80 & $1.33 \times 10^{-4}$ \\
\hline Standard & 50 & 7.87 & 2.40 & $3.34 \times 10^{-5}$ \\
\hline
\end{tabular}

Table 3. Dissolution of dominant metal ions in AMD.

\begin{tabular}{ccccc}
\hline & Fly ash (\%) & $\mathrm{Al}(\mathrm{ppm})$ & $\mathrm{Fe}(\mathrm{ppm})$ & $\mathrm{Mn}(\mathrm{ppm})$ \\
\hline & 0 & 34.1 & 298 & 14.2 \\
Acidic Soil 1 & 5 & 5.4 & 143 & 8.1 \\
& 10 & 15.7 & 161 & 9.3 \\
& 20 & 17.6 & 143 & 9.3 \\
& 50 & 14.1 & 17 & 0.2 \\
\hline \multirow{4}{*}{ Acidic Soil 2 } & 0 & 20.2 & 1067 & 20.7 \\
& 5 & 24.6 & 1167 & 23.5 \\
& 10 & 14.4 & 814 & 17.8 \\
& 20 & 31.8 & 705 & 16.2 \\
& 50 & 26.2 & 187 & 6.4 \\
\hline
\end{tabular}

\subsection{Laboratory vegetation test}

In order to discuss the applicability of fly ash on acidic conditions to promote the plant growth, Acacia mangium was planted on the prepared soils mixed with acidic soil and fly ash described in previous section. The plants were placed in the phytotron glass room G-9 in Biotron Application Center, Kyushu University under the 
following conditions: at $30^{\circ} \mathrm{C}$ room temperature and $70 \%$ relative humidity assuming the tropical climate. In this test, 5 plants were planted in each soil, and measured the height and the basal diameter every a week. At the end of the test, the dry weight of Acacia mangium was measured. This vegetation test continued for 11 weeks until a clear distinction is observed. All pots were supplied with $500 \mathrm{~mL}$ water every $3 \sim 4$ day, while liquid fertilizer HYPONeX fomula 6-10-5 diluted to 1,000 ppm with water was, additionally, added to them weekly. The data obtained from the laboratory vegetation test are processed by using Tukey-kramer method to indicate the significant differences among the each result.

\section{Results and Discussion}

\subsection{Preparation of simulated acidic soil}

Figures 1 (a) and (b) shows the photo of Acasia mangium at the end of the test. We also prepared the pots of decomposed granite soil without pyrite and fly ash as a control pot. It can be clearly observed that the growth of Acasia mangium is promoted with mixing of fly ash in acidic soil 1 whereas the most of the plants does not grow in acidic soil 2. Figures 2 (a), (b) and 3 (a), (b) show the increment of plant height and basal diameter. These increment are found in acidic soil 1 with $5 \%, 10 \%$, and $20 \%$ of fly ash with elapsed time though the other soil show the slightly increase or no improvement due to the death of plant. The height increase of the plants is improved in acidic soil 1; acidic soil 1 with $10 \%$ of fly ash addition show the highest height $(47.3 \mathrm{~mm})$ followed by $5 \%$ of fly ash addition $(40.6 \mathrm{~mm})$ at the end of the test while the height increase of the control pots is $110.5 \mathrm{~mm}$. The basal diameter increase showed similar pattern with that of height. Maximum basal diameter was found in acidic soil 1 with $10 \%$ of fly ash $(0.90 \mathrm{~mm})$ followed by $5 \%$ of fly ash addition $(0.86$ $\mathrm{mm}$ ) while the basal diameter of the control pots is $1.80 \mathrm{~mm}$. The slightly increments or no improvements of both of plant height and basal diameter are found in acidic soil 2.

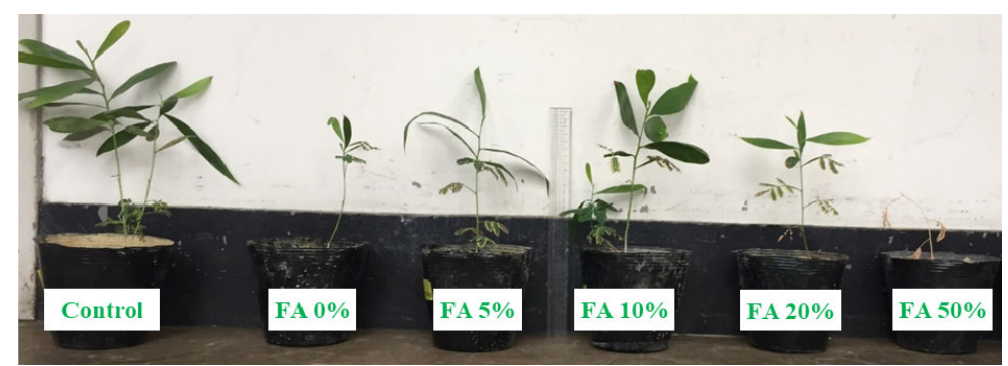

(a) Acidic soil 1 


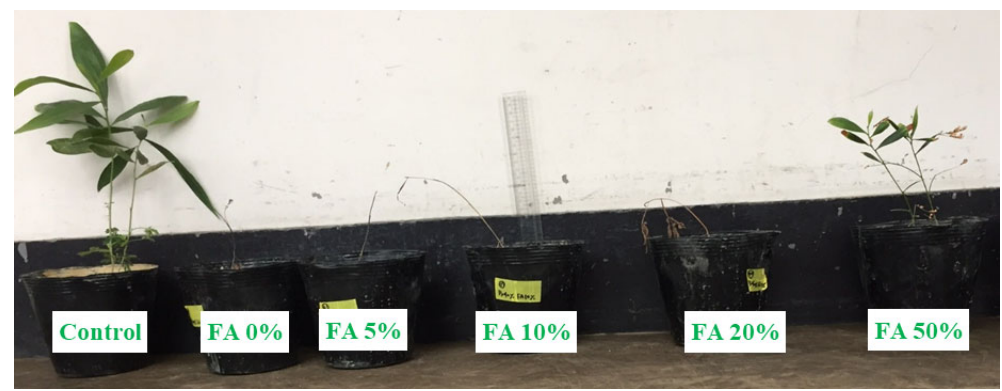

(b) Acidic soil 2

Fig. 1. Photo of Acacia mangium at the end of test: (a) Acidic soil 1, (b) Acidic soil 2.

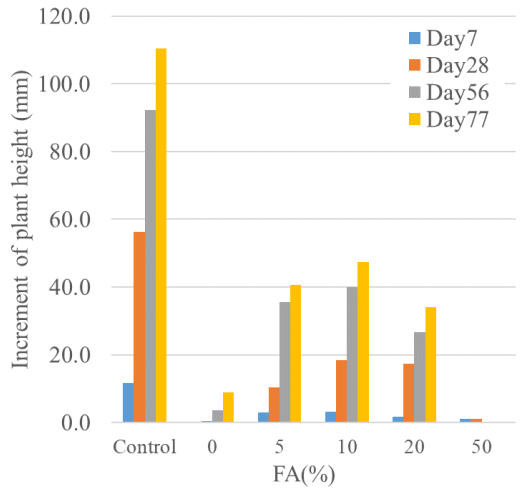

(a) Acidic soil 1

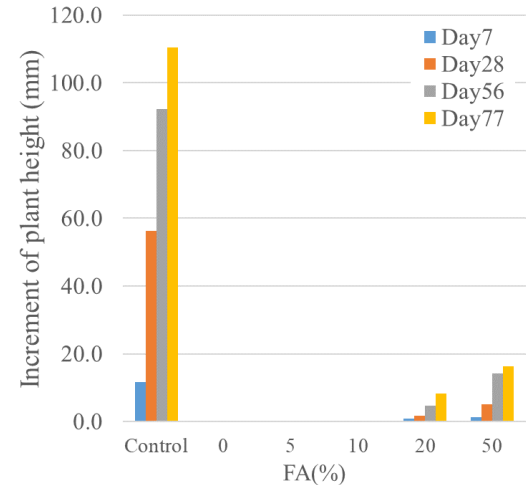

(b) Acidic soil 2

Fig. 2. Increment of plant height: (a) Acidic soil 1, (b) Acidic soil 2.

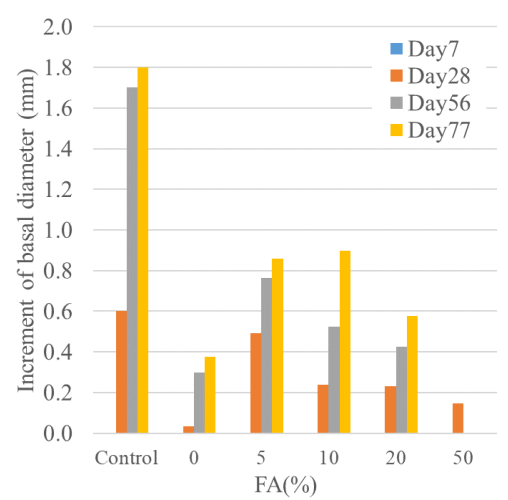

(a) Acidic soil 1

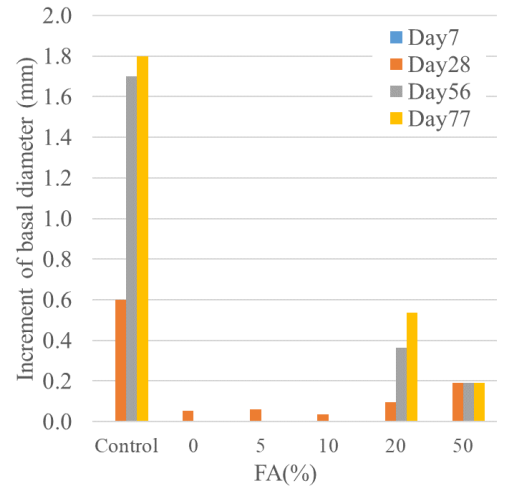

(b) Acidic soil 2 
Fig. 3. Increment of basal diameter: (a) Acidic soil 1, (b) Acidic soil 2.

Dry weight of Acasia Mangium is a proper parameter to discuss the impact of soil conditions on the plant growth in terms of biomass. Multiple comparison analysis of dry weight revealed significant differences between the pots in acidic soil 1 (Fig. 4). The dry weight is significantly increased in acidic soil 1 with $5 \%(0.88 \mathrm{~g})$ and $10 \%$ $(0.71 \mathrm{~g})$ of fly ash followed by $20 \%$ of fly ash $(0.39 \mathrm{~g})$ while the weight of the control pots is $1.14 \mathrm{~g}$. The $5 \%$ of fly ash seems appropriate to promote the plant growth because the results does not show statistically difference with a control. The pots of acidic soil 1 with $0 \%$ and $50 \%$ does not promote plant growth. Considering that the inhibition of the growth of plants by aluminum is a major problem in acidic conditions, the content of Al dissolved under the acidic condition may affect the growth of Acacia mangium in the $0 \%$ of fly ash. The dry weight is declined with an increase of fly ash addition under the alkaline conditions. The decline of the dry weight is probably due to salinity caused by sulphate, chloride, carbonate, bicarbonate from fly ash. Additionally, the reduction of absorbing the nutrient under the alkaline condition is also a factor to inhibit the plant growth. On the other hands, the results of acidic soil 2 does not show statistically different between the pots. The significant inhibitions of plant growth in acidic soil 2 is due to the osmotic stress caused by high salinity and the specific effects of individual ions. Previous research indicated water uptake by the root is reduced if there is osmotic stress [19]. The electric conductivity of acidic soil 2 shows quite higher compared to the standard value (Table 2), meaning that the water uptake by roots is inhibited due to the effects of osmotic stress. Besides, the specific ions should influence the plant growth because excessive metal ions dissolved. Therefore, the metal accumulation in the plant body will be investigated as the future task.

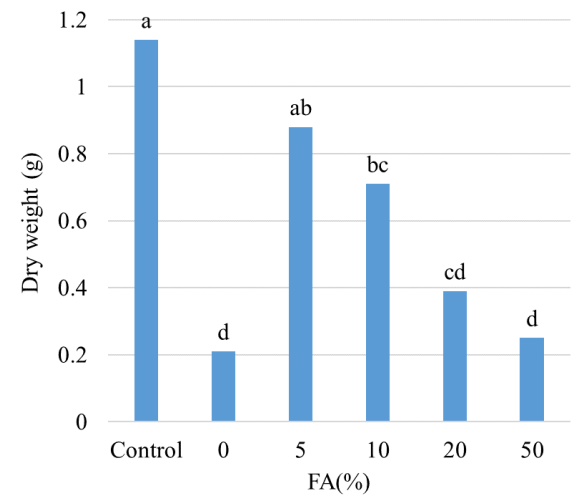

(a) Acidic soil 1

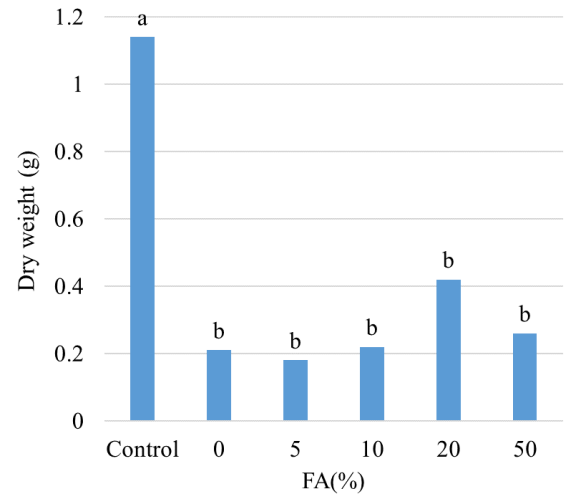

(b) Acidic soil 2

Fig. 4. Increment of basal diameter: (a) Acidic soil 1, (b) Acidic soil 2. 


\section{Conclusions}

Vegetation process is necessary after mining operation in terms of environmental conservation. However, acid sulfate soils attributed to the process of backfill of waste rocks in post-mining area inhibit plant growth in revegetation stage in some cases. It seems to be effective way to neutralize the acidic soil by using fly ash which has alkaline properties. In this research, laboratory vegetation test was performed with Acacia Manguim for 11 weeks in order to understand the effects of fly ash addition to acid-topsoil on plant growth. According to the results, it is possible to improve the plant growth under the acidic soil by remediating soil conditions with fly ash addition though excess of fly ash inhibits the plant growth due to the salinity and alkalization of soils. Moreover, it is difficult to improve the plant growth by using fly ash if the acidic soil has the high potential of metal dissolution. As a summary, effective revegetation by using fly ash is possible to be performed by evaluating the effect of metal dissolution from acidic soil and fly ash on plant growth.

\section{References}

1. Sheoran, V., Sheoran, A. S., Poonia, P.: Soil reclamation of abandoned mine land by revegetation: a review. Int. J. Soil, Sediment Water 3(2) (2010) 1-21

2. Takeuchi, K. Shimano, K.: Vegetation succession at the abandoned Ogushi sulfur mine, central Japan. Landscape Ecol. Eng. 5(1) (2009) 33-44

3. Ueno, K.: A Mechanism of Soil Acidification in Acid Sulfate Soils. Annu. Rep. Res. Inst. Biol. Funct. 4 (2004) 25-33 (in Japanese)

4. Matsumoto, S., Ogata, S., Dwiki, S., Hideki, S., Sasaoka, T.: Fundamental Research on Evaluation of Acid-Topsoil for Effective Revegetation at Post-Mining Land in Indonesian Open Cast Coal Mine. Proc. of International Symposium on Earth Science and Technology 2015 (2015) 65-69

5. Ogata, S., Matsumoto, S., Hideki, S., Sasaoka, T.: Study on Effective Revegetation at PostMining Land in Indonesian Open-cut Coal Mine. Proc. of International Symposium on Earth Science and Technology 2016 (2016) 352-356

6. Anawar, H. M., Canha, N., Santa-Regina, I., Freitas, M. C..: Adaptation, tolerance, and evolution of plant species in a pyrite mine in response to contamination level and properties of mine tailings: sustainable rehabilitation. J. Soils Sediments 13(4) (2013) 730-741

7. Pandey, V. C., Abhilash, P. C., Singh, N.: The Indian perspective of utilizing fly ash in phytoremediation, phytomanagement and biomass production. J. Environ. Manage. 90(10) (2009) 2943-2958

8. Capp, J. P., Adams, L. M.: Reclamation of coal mine wastes and strip spoil with fly ash. Proc. of Economic use of surface-mined land and mine refuse symposium (1971) 26-37

9. Srivastava, A., Chhonkar, P. K.: Amelioration of coal mine spoils through fly ash application as liming material. J. Sci. Ind. Res. 59(4) (2000) 309-313

10. Brown, T. H., Bland, A. E., Wheeldon, J. M.: Pressurized fluidized bed combustion ash .2. Soil and mine spoil amendment use options. Fuel 76(8) (1997) 741-748

11. Fail, J. L., Wochok, Z. S.: SOYBEAN GROWTH ON FLY ASH-AMENDED STRIP MINE SPOILS. Plant Soil 48(2) (1977) 473-484

12. Khan, M. R., Khan, M. W.: The effect of fly ash on plant growth and yield of tomato. Environ. Pollut. 92(2) (1996) 105-111 
13. Singh, L. P., Siddiqui, Z. A.: Effects of fly ash and Helminthosporium oryzae on growth and yield of three cultivars of rice. Bioresour. Technol. 86(1) (2003) 73-78

14. Matsi, T., Keramidas, V. Z.: Fly ash application on two acid soils and its effect on soil salinity, pH, B, P and on ryegrass growth and composition. Environ. Pollut. 104(1) (1999) $107-112$

15. Mishra, L. C., Shukla, K. N.: EFFECTS OF FLY-ASH DEPOSITION ON GROWTH, METABOLISM AND DRY-MATTER PRODUCTION OF MAIZE AND SOYBEAN. Environ. Pollut. Ser. Ecol. Biol. 42(1) (2009) 1-13

16. Research Committee of Japanese Institute of Landscape Architecture: Ground Maintenance Manual in Landscape Planting. J. Jpn. Inst. Landscape Archit. 63(3) (2000) 224-241 (in Japanese)

17. Kochian, L. V., Pineros, M. A., Hoekenga, O. A.: The physiology, genetics and molecular biology of plant aluminum resistance and toxicity. Plant Soil 274(1-2) (2005) 175-195

18. Kikui, S., Sasaki, T., Maekawa, M., Miyao, A., Hirochika, H., Matsumoto, H., Yamamoto, Y.: Physiological and genetic analyses of aluminium tolerance in rice, focusing on root growth during germination. J. Inorg. Biochem. 99(9) (2005) 1837-1844

19. Bernstein, L.: EFFECTS OF SALINITY AND SODICITY ON PLANT-GROWTH. Annu. Rev. Phytopathol. 13 (1975) 295-312 